\title{
PERADILAN GAMPONG SEBAGAI WADAH DALAM MENYELESAIKAN SENGKETA WARISAN DI PROVINSI ACEH
}

\author{
Rahmat Fitrah \\ Fakultas Ilmu Sosial dan Politik Universitas Teuku Umar \\ memect_12@yahoo.com
}

\begin{abstract}
Legally, it is known there are two ways of settling disputes, first settling disputes in litigation that is in court, and both are known by way of non-litigation dispute resolution outside the court that. With the existence of alternative dispute resolution such as non-litigation, the court only used as a last choice by the parties to resolve the dispute. In Aceh disputes in society more dominant resolved through Customary Council, as a matter of dispute inheritance, because according to them more in line with a growing sense of justice in society.
\end{abstract}

Keyword: Justice Gampong,Resolving Disputes. 


\section{LATAR BELAKANG}

Hukum adat merupakan keseluruhan aturan yang ditetapkan dalam keputusan-keputusan para petugas yang berwenang dan didalam pelaksanaannya dilansir secara polos, artinya itu dilaksanakan tanpa membawa terbentuknya suatu keseluruhan aturan-aturan yang sejak saat lahirnya dinyatakan mengikat secara mutlak untuk masa yang akan datang. Dengan demikian hukum adat yang berlaku di Indonesia hanya dapat diketahui dari keputusan-keputusan sebagaimana diambil oleh penguasa-penguasa dalam masyarakat.

Indonesia adalah Negara yang bersifat pluralisme, baik suku, budaya, bahasa, maupun agama. Keberagaman tersebut mengakibatkan pula keberagaman hukum sebagai fakta yang tidak dapat dihindari. Negara Indonesia dengan tegas mengakui dan menghormati kesatuan masyarakat hukum adat beserta hak-hak tradisionalnya sepanjang masih hidup dan sesuai dengan perkembangan masyarakat dan prinsip Negara Kesatuan Republik Indonesia yang di atur dalam Undang-Undang. Hukum adat merupakan bagian hukum yang berlaku di Indonesia sehingga keberadaan hukum adat tersebut menjadi bukti yang konkrit bahwa Indonesia mengakuai pluralisme.

Negara Indonesia sebagai Negara yang memiliki keberagaman hukum, memang telah memiliki Undang-Undang Nomor 49 Tahun 2009 Tentang Peradilan Umum yang bertujuan memusatkan segala perkara umum ke pengadilan umum nasional, namun sampai saat ini Indonesia belum mempunyai undang-undang yang secara tegas mengatur kedudukan dan kekuatan hukum adat sebagai alat bukti terhadap putusan pengadilan, baik perdata maupun pidana.

Secara yuridis, telah dikenal ada dua macam penyelesaian perkara dalam masalah hukum, yang pertama dikenal dengan penyelesaian litigasi, dan kedua yang dikenal dengan non litigasi. Litigasi yaitu penyelesaian di depan pengadilan, seperti penyelesaian perkara di Peradilan Umum, PeradilanAgama atau Mahkamah Syari'ah, Peradilan Militer, danPeradilan Tata Usaha Negara. Peradilan tersebut dikelolaoleh negara, dan sering disebut dengan nama government judicial system. Non litigasi yaitupenyelesaian perkara di luar pengadilan seperti secara adat, arbitrase,mediasi, dsb.

Dengan adanya penyelesaian sengketa alternatif, maka pengadilan hanya dijadikan sebagai pilihan yang terakhir oleh para pihak yang menyelesaikan sengketa. Para pihak yang bersengketa baru akan mengajukan perkaranya ke pengadilan apabila lembaga penyelesaian sengketa alternatif tidak mampu menanganinya. Di Indonesia, disamping pengadilan sebagai forum penyelesaian sengketa yang keberadaannya diakomodir oleh Negara melalui UndangUndang No. 48 Tahun 2009 tentang Kekuasaan Kehakiman, terdapat juga forum penyelesaian sengketa lain yang mengacu pada pranata adat dan agama. Hal tersebut dilatar belakangi karena adanya pluralisme hukum yang berlaku di Indonesia, dimana hukum yang berlaku bukan hanya hukum yang berasal dari negara, melainkan juga berlakunya hukum yang berasal dari adat serta hukum yang berasal dari agama.

Titik awal bagi pengadilan non litigasi yang diakui oleh kolonial Belanda pada Tahun 1935 lewat Statblaad 1935 No. 102. Pengakuan ini didorong oleh bentuk politik balas budi yang diperankan oleh Belanda terhadap wilayah jajahannya. Kebijakan politik demikian ternyata juga memberi peluang positif terhadap bentuk peradilan yang tidak dikelola oleh negara. Dengan demikian, melalui kebijakan tersebut dapat ditegaskan bahwa Belanda telah mengakui keberadaan Peradilan Adat dan Peradilan Agama saat itu. Meskipun pengakuan tersebut masih bersifat terbatas, seperti hakim-hakim adat tidak diperbolehkan menjatuhkan hukuman. Bukan hanya Peradilan Desa yang diakui, tetapi juga Peradilan Adat dan Peradilan Swapraja juga turut diakui.

Bangsa Indonesia memiliki adat istiadatnya masing-masing, tidak lain juga seperti di Aceh. Dalam pelaksanaanya berada dan dikendalikan oleh lembaga-lembaga adat yang sesuai dengan lingkungannya sebagai organisasi kemasyarakatan. Maka lembaga Adat di Aceh 
merupakan suatu organisasi kemasyarakatan yang dibentuk oleh masyarakat hukum adat yang mendiami wilayah tertentu dan berhak mengatur dan mengurus wilayahnya sendiri, untuk menyelesaikan hal-hal yang berkaitan dengan kebutuhan dan ketertiban masyarakat, keberadaan hukum adat ini dikuatkan dengan Undang-Undang Dasar 1945 Pasal 18b dan Undang- Undang Nomor 11 Tahun 2006 Tentang Pemerintah Aceh.

Aceh merupakan Provinsi yang bersifat Khusus dan Istimewa, dalam upaya meningkatkan pembinaan dan pelestarian adat istiadat, Pemerintah Aceh telah membentuk lembaga khusus yang disebut dengan Lembaga Adat dan Kebudayaan Aceh (LAKA). Pembentukan LAKA pada 9 Juli 1986 merupakan bagian yang tidak dapat terpisahkan dari sejarah sosial masyarakat Aceh itu sendiri, kemudian pada Tahun 2003 mengalami perubahan menjadi Majelis Adat Aceh (MAA). MAA ini lahir berdasarkan Keputusan Kongres Adat Aceh yang diselenggarakan oleh LAKA (Lembaga Adat dan Kebudayaan Aceh) pada Tahun 2002 di Banda Aceh, ini dilakukan berdasarkan perkembangan dinamika kehidupan masyarakat Aceh, berpijak pada UndangUndang Nomor 44 Tahun 1999 Tentang Penyelenggaraan Keistimewaan Aceh, dimana salah satunya adalah Keistimewaan dibidang Penyelenggaraan adat istiadat masyarakat Aceh. Kongres ini dibuka resmi oleh Presiden Republik Indonesia yang saat itu di jabat oleh Megawati Soekarno Putri di bandara Sultan Iskandar Muda, kehadiran presiden di Aceh saat itu dalam rangka meresmikan penerbangan perdana pesawat Selawah Air NAD milik pemerintah Provinsi Aceh.

Kongres Adat selanjutnya mengesahkan LAKA (Lembaga Adat dan Kebudayaan Aceh) menjadi MAA (Majelis Adat Aceh), kemudian penetapan status hukum dengan membentuk Qanun Nomor 3 Tahun 2004 Tentang pembentukan Sususunan Organisasi dan Tata Kerja Majelis Adat Aceh. Organisasi Majelis Adat Aceh ini kemudian dibentuk tingkat Provinsi,Perwakilan Provinsi dan Kabupaten/Kota, hingga lahirlah Majelis Adat Kabupaten Aceh Besar dan Majelis Adat Aceh di Kabupaten-kabupaten lainnya sampai dengan pembentukan Majelis Adat Tingkat Kecamatan, Mukim, hingga ke Gampong-Gampong di Provinsi Aceh. Sedangkan biaya operasionalnya di anggarkan pada APBA untuk tinggkat Provinsi dan APBK di tingkat Kabupaten/Kota.

Lembaga adat yang berkebang dalam kehidupan masyarakat Aceh sejak dahulu hingga saat ini mempunyai peran penting dalam membina nilai-nilai yang hidup dalam masyarakat, norma-norma adat, dan aturan untuk mewujudkan keamanan, ketertiban, ketenteraman, kerukunan, dan kesejahteraan bagi masyarakat Aceh sesuai dengan nilai-nilai Islam

Majelis Adat Aceh juga bertujuan untuk membina dan mengembangkan adat istiadat agar tidak hilang dan selalu terjaga sepanjang zaman, ini dikarenakan didalam adat tersebut sungguh banyak terkandung nilai-nilai lebih bagi masyarakat yang sehingga dapat menjadi petaka bagi masyarakat bila nilai-nilai adat ini hilang dan pupus di tengah kehidupan masyarakat. Kehidupan masyarakat adat di Aceh dapat berkembang, meluas, dan menipis, bahkan dapat menghilang, ini tergantung pada dinamika kehidupan masyarakat hukum adatnya dan amat tergantung pula pada kemampuan masyarakat itu sendiri dalam memberdayagunakan adat istiadatnya dan mengikuti arus perkembangan sosial budaya luar dan perkembangan ilmu pengetahuan.

Pembangunan masyarakat dan bangsa tidak semata-mata pada pembangunan fisik, melainkan juga membangun adat istiadat yang dimiliki sebagai landasan identitas, harkat dan martabat kehidupannya, serta menjadi aset khasanah kekayaan bangsa. Bagi masyarakat Aceh membangun adat dan budaya yang disertai dengan syari'at merupakan suatu keharusan, karena nilai-nilai adat dan syari'at dapat menjadi perekat kekuatan kesatuan dan persatuan Aceh dalam membangun kesejahteraan hidup.

Penyelesaiaan sengketa secara adat yang dilakukan oleh masyarakat Aceh bukan sematamata dijalankan karena adanya pengakuan dari Undang-Undang, melaikan mempunyai sebuah 
ketentuan adat yang tumbuh dan ikut dalam kehidupan bermasyarakat sehingga menjadi suatu marwah bila diselesaikan sengketa melalui adat.

Bagi masyarakat Aceh, hukum adat merupakan hukum yang menjadi pedoman dalam tatanan kehidupan sosial masyarakatnya. Hukum adat yang berlaku di Aceh merupakan kebiasaan yang dilakukan pada masa kesultanan sehingga dilangsungkan secara terus menerus demi terciptanya keseimbangan dalam kehidupan masyarakat. Selain itu, hukum adat di Aceh merupakan kombinasi dari hukum Islam yang tidak dapat dipisahkan, sehingga ada istilah yang berbunyi 'hukom ngoen adat lagee zat ngoen sifeut' artinya 'hukum dengan adat seperti zat dengan sifat dari zat tersebut' betapa sulit dipisahkan.

Hal itu terjadi sejak dari masa kesultanan, disamping berlakunya hukum positif yang berdasarkan syari'at islam yang menjadi hukum resmi dalam kerajaan, juga berlaku hukum adat yang pada dasarnya seiring berjalan tanpa bertentangan dengan dengan hukum Islam. Dewasa ini masyarakat Aceh sudah tidak lagi mempermasalahkan perbedaan antara hukum adat dan hukum Islam karena apa yang ada dalam hukum adat tentu telah dibolehkan dalam hukum Islam, sehingga menjadi satu kesatuan.

Di Aceh hukum agama dan hukum adat memegang peranan penting dalam masyarakat, walaupun hukum adat pernah mengalami kevakuman di Aceh pada masa orde baru, di karenakan konflik yang berkepanjangan antara Pemerintah Republik Indonesia (RI) dan Gerakan Aceh Merdeka (GAM) terus berlanjut. Konflik bersenjata yang terjadi di Aceh pada awal reformasi menyebabkan banyak efek dari kebijakan Pemerintah Indonesia dibawah rezim reformasi tidak berkembang, termasuk kebijakan otonomi daerah. Kondisi ini menyebabkan revitalisasi adat di Aceh tidak seiring dengan terjadi didaerah lain di Indonesia. Namun demikian di Aceh bukannya tidak ada usaha kearah revitalisasi, beberapa kebijakan Pemerintah Indonesia dan pemerintah lokal di Aceh memberikan dampak pada usaha revitalisasi adat tersebut dengan dilahirkannya Undang-Undang No.40 Tahun 1999 Tentang Keistimewaan Aceh, yang menegaskan kembali bahwa Aceh adalah Daerah Istimewa dalam bidang adat, agama, dan pendidikan. Dalam Undang-Undang No.40 Tahun 1999 Tentang Keistimewaan Aceh ini pada Pasal 3 ayat (2) menerangkan, penyelenggaraan keistimewaan tersebut meliputi : (1) penyelenggaraan kehidupan beragama, (2) penyelenggaraan kehidupan adat, (3) penyelenggaraan pendidikan dan (4) peran ulama dalam menetapkan kebijakan daerah. Berdasarkan undang-undang ini pemerintah memberikan ruang bagi masyarakat adat lokal untuk bangkit dan menenun kembali adat yang ada dalam masyarakat Aceh.

Setelah perdamaian terjadi, maka lahirlah Undang-Undang No.11 Tahun 2006 Tentang Pemerintah Aceh didalamnya juga mempertegas mengenai Lembaga Adat yang kemudian diatur lebih lanjut dalam Qanun, seperti Qanun No.9 Tahun 2008 tentang Pembinaan Kehidupan Adat Dan Adat Istiadat serta Qanun No.10 Tahun 2008 tentang Lembaga Adat dan juga yang tergolong baru adalah Peraturan Gubernur No. 60 Tahun 2013 Tentang Pelaksanaan Penyelesaian Sengketa/ Perselisihan Adat dan Istiadat.

Bila melihat badan penyelesaian perkara peradilan adat di Aceh, semua tergabung dalam Majelis adat, pada umumnya penyelenggaraan peradilan perdamaian adat diselenggarakan di tingkat peradilan adat Gampong dan peradilan Mukim. Hal ini berlaku untuk seluruh Aceh. Gampong mempunyai kepemerintahan tersendiri, yang mana juga memiliki tatanan aturan dan kepengurusan serta kekayaannya sendiri. Gampong atau Desa ini merupakan organisasi terendah dalam susunan kepemerintahan Negara Republik Indonesia dan ditetapkan dengan Qanun Nomor 5 Tahun 2003 Tentang Pemerintahan Gampong.

Didalam pemerintahan Gampong, Geuchik memiliki peranan dan kekuasaan dalam pembinaan, pengembangan adat juga pelaksanaan peradilan adat dan memutuskan setiap perkara/sengketa yang di bantu oleh perangkat gampong. Pusat kegiatan masyarakat dan kegiatan adat Gampong yaitu di meunasah. Meunasah ini sebagai pusat komonitas sosial, budaya, politik dalam masyarakat, yang secara umum berfungsi sebagai: 
a. Tempat ibadah

b. Dakwah dan diskusi

c. Musyawarah/meupakat

d. Penyelesaiaan Sengketa

e. Pengembangan seni

f. Pembinaan dan tempat berkumpulnya generasi muda

g. Penyelenggaraan Forum

Kawasan Gampong dan Mukim terdapat lembaga-lembaga adat lainnya, yang independen dan otonom dalam menyelenggarakan tugas khusus yaitu bidang ekonomi dan kesejahteraan masyarakat, meliputi bidang pertanian, perkebunan/kehutanan, peternakan, kelautan dan pasar/perdagangan, dll. Seperti di tentukan pada Qanun Nomor 5 Tahun 2003 Tentang keperintahan Gampong, dalam pasal 28 huruf b telah disebutkan unsur pelaksanaan teknis fungsional, melaksanakan tugas-tugas tertentu sesuai dengan kebutuhan dan kondisi sosial ekonomi masyarakat, lembaga-lembaga tersebut adalah:
a. Keujreun Blang
b. Panglima laot
c. Peutuwa Seuneubok
d. Haria Peukan
e. Syahbanda

Perangkat Gampong bila ditinjau dari segi adat terdiri dari Geuchik, Imuem Meunasah, Tuha Peut, Sekretaris Gampong, Ulee Jurong, dan Ulama/Cendikiawan. Selain pemerintahan Gampong yang di pimpin oleh geuchikjuga ada pemerintah Mukim yang di pimpin oleh Imиem Mukim. Mukim terdiri dari gabungan beberapa gampong, yang mempunyai batas wilayah adatnya masing-masing dan juga asset masing-masing. Mukim ini berkedudukan didalam wilayah Kecamatan, diatur dengan Qanun Aceh Nomor 4 Tahun 2003 Tentang Mukim.

Mukim di pimpin oleh Imuem Mukim dengan dibantu oleh sekretaris Mukim dan Tuha Peut Mukim. Sebagai pemimpin adat dan juga Kepala Pemerintahan Mukim mempunyai tugas mengendalikan lembaga adat Mukimyang menyangkut dengan adat istiadat dan hukum adat, peradilan adat, serta menjaga jalannya Syari'at Islam, seperti di jelaskan dalam Qanun Aceh Nomor 4 Tahun 2003 Tentang Mukim. Pada umumnya kegiatan Mukim berada di masjid, namun karena perkembangan sosial masyarakat maka kegiatan Imuem Mukim di alihkan ke luar masjid, karena lebih banyak berhubungan dengan kesejahteraan dan ketertiban masyarakat. Mesjid kemudian dipimpin oleh Imuem Chiek, yang tugas utamanya lebih banyak menyangkut dengan ibadah dan syariat. Dengan demikian fungsi masjid sebagai salah satu simbol ke-Aceh-an, menunjuk pada sentra komunikasi manusia dengan Tuhannya (Hablumminallah) dan dengan sesama manusia (Hablumminannas). Dengan demikian fungsi masjid dapat dimanfaatkan sebagai berikut:
a. Tempat ibadah/Shalat Jum'at
b. Pendidikan Islam/mengaji
c. Musyawarah/ penyelesaiaan sengketa
d. Dakwah/penyiaran nilai-nilai Agama
e. Acara Pernikahan
f. Logo persatuan dan kesatuan ummat.

Badan perlengkapan peradilan adat di tingkat Mukim dan mekanisme kerjanya hampir sama dengan peradilan adat di tingkat Gampong. Ruang kerjanya berada pada kasus yang terjadi di antar gampong yang berada dalam wilayah Mukim dan kasus yang tidak bisa diselesaikan di tingkat gampong. Seperti di tetapkan dalam Qanun Nomor 4 Tahun 2003 Tentang Pemerintahan Mukim, antara lain: 
- Lembaga Mukim berwenang untuk memutuskan dan/atau menetapkan hukum dalam hal adanya persengketaan- persengketaan atau perkara-perkara adat dan hukum adat (pasal 4 huruf e);

- Majelis adat mukim berfungsi sebagai badan yang memelihara dan mengembangkan adat, menyelenggarakan perdamaian adat, menyelesaikan dan memberikan keputusan-keputusan adat terhadapa perselisihan dan pelanggaran adat, memberikan kekuatan hukum terhadap suatu hal dan pembuktian lainnya menurut adat [pasal 12 ayat (2)].

Khusus untuk yang menyangkut dengan kasus yang diteruskan ketingkat mukim, didalam Qanun Nomor 5 Tahun 2003 Tentang Pemerintahan Gampong menegaskan bahwa:

"Pihak yang berkeberatan terhadap keputusan perdamaiaan sebagaimana simaksud pasal

12 ayat (2), dapat meneruskannya kepada Imиem Mukim dan keputusan Imиem Mukim bersifat final dan mengikat [pasal 12 ayat (3)]."

Peradilan adat Mukim merupakan upaya terakhir untuk mendapatkan peradilan setelah peradilan adat Gampong, dalam yurisdiksi. Perkara-perkara atau sengketa-sengketa yang tidak dapat diselesaikan pada tingkat mukim, akan dilimpahkan ke lembaga peradilan Negara, sesuai dengan ketentuan undang-undang dan peraturan yang berlaku di Negara.

Pelimpahan kasus tidak hanya dapat dilakukan dari peradilan adat ke Peradilan formal namun juga dapat dilakukan sebaliknya, yaitu dari peradilan formal ke peradilan adat, ini dapat terjadi dikarenakan beberapa hal seperti :

1. Bukan ruanglingkup dari jurisdiksi adat.

2. Kasus-kasus yang tidak dapat diselesaikan di peradilan adat.

Kasus-kasus yang bukan ruanglingkup dari peradilan adat walaupun hal tersebut terjadi dalam jurisdiksi adat, seperti perzinahan, pembunuhan, pemerkosaan, narkoba dan sejenisnya, pencurian berat (kerbau, kendaraan bermotor dan lain-lain) surversif, penghinaan terhadap pemerintah yang sah (Presiden dan Gubernur), kecelakaan lalu lintas berat yang menimbulkan kematian, penculikan dan perampokan bersenjata, maka oleh itu Geuchik segera memberitahukan kepada pihak kepolisian (Polsek), pemberitahuan tersebut baik secara tulisan maupun lisan.

Sebenarnya sepanjang catatan sejarah di Aceh masih ada peradilan lain di atas Mukim, namun sekarang sudah ditiadakan karena pengaruh perkembangan zaman, yaitu sejak masa Sultan Iskandar Muda, pada tahun 1607-1636 kekuasaan peradilan di pegang oleh lembaga yang bernama Qadhi Malikul Adil di tingkat kerajaan, dan Qadhi Ulee Balang di setiap daerah, selanjutnya ada Qadhi Mukim dan yang paling rendah Ureung Tuha Gampong (Peradialan tingkat Gampong).

Namun diantara keseluruhannya, maka geuchik sangatlah berperan besar sebagai pengendali sosial masyarakat didesa dalam mengatur setiap kebijakan yang berada dalam wilayah hukumnya, termasuk di dalamnya kebijakan tentang hukum syari'at Islam dan sengketa pembagian warisan. Penyelesaiaan sengketa/perkara melalui peradilan adat gampong atau mukim tetap dirasakan perlu oleh masyarakat Aceh, bila dilihat dari penyelesaiaan sengketa warisan didalam kalangan masyarakat Aceh maka Majelis Adat telah banyak menyelesaikan berbagai masalah yang timbul dalam pembagian warisan. Seperti dikatakan oleh Professor Mahadi, bahwa hukum adat itu lebih efektif dan dipatuhi oleh karena adanya orang yang mengingatkan, meski tidak tertulis.

Berdasarkan latar belakang diatas, maka muncul rumusan masalah yang menarik untuk dilakukan penelitian adalah sejauh mana ruang lingkup penanganan sengketa oleh Majelis Adat Aceh dan apa yang menjadi dasar hukum Majelis Adat Aceh dalam mengambil keputusan sengketa warisan? 


\section{METODOLOGI PENELITIAN DAN KERANGKA TEORI Metode Penelitian}

Penelitian ini merupakan penelitian yuridis empiris yang bersifat analitis dengan pendekatan deskriptif. Melalui pendekatan deskriptif ini dimaksudkan untuk menggambarkan secara sistematis, faktual tentang keakuratan fungsi Majelis Adat bersamaan dengan pelaksanaan hukum adat dalam prilaku masyarakat serta konteksnya dengan teori-teori sumber hukum berkenaan dengan permasalahan yang diajukan. Melalui yuridis empiris, penelitian ini dilakukan dari aspek perkembangan, dengan terlebih dahulu meneliti berbagai peraturan serta bahan-bahan kepustakaan yang ada, kemudian menghubungkannya dengan yuridis empiris dari fenomena-fenomena data lapangan dengan kaedah-kaedah adat yang hidup dalam masyarakat, terutama yang berkaitan dengan Majelis Adat Aceh.

\section{Kerangka Teori}

Teori yang digunakan dalam penelitian ini adalah teori efektifitas, memperlihatkan keanekaragaman dalam hal indikator penilaian efektivitas suatu hal. Efektif adalah taraf sejauh mana suatu kelompok dapat mencapai tujuannya. Hukum dapat dikatakan efektif jika terdapat dampak hukum yang positif,pada saat itu hukum mencapai sasarannya dalam membimbing ataupun merubah perilaku manusia sehingga menjadi perilaku hukum.

\section{HASIL PENELITIAN DAN PEMBAHASAN \\ Ruang Lingkup Penanganan Sengketa Oleh Majelis Adat Aceh}

Pembentukan peradilan adat di Gampong-Gampong di Aceh tidaklah dimaksudkan dalam pengertian dengan adanya surat keputusan resmi dari pemerintah dan berdasarkan perundang-undangan yang berlaku dalam sistem peradilan nasional Indonesia, seperti pembentukan pengadilan Negeri atau Mahkamah Syari'ah dan /atau lainnya. Sistem peradilan Indonesia telah ditetapkan dalam suatu sistem peradilan Nasional yang sekarang ini berdasarkan Undang- Undang Nomor 48 Tahun 2009 Tentang Kekuasaan kehakiman.

Peradilan bila di pandang dari segi hukum tentu dimaksudkan dalam hubungan pengurusan berbagai persengketaan, baik perdata maupun pidana, yang mengharuskan diselesaikan oleh lembaga-lembaga pengadilan Nasional dalam pengertian memerlukan upaya hukum untuk di selesaikan, bila perlu dengan berbagai saksi, berdasarkan Undang-undang yang berlaku karena tidak ada jalan lain untuk mendapatkan keadilan, kecuali dengan jalan mendapatkan vonis dari pengadilan oleh hakim.

Disinilah terletak perbedaannya dengan peradilan adat, yang bersifat tidak tertulis, namun pasti dan tercapainya persepakatan bersama dengan jalan damai dan juga seimbang. Peradilan adat tidak ada sanksi hukum seperti pada pengadilan Nasional, melainkan mengacu pada harkat dan martabat keadilan yang seimbang dan sejahtera.

Adat bila dikaji dengan ilmu pengetahuan dapat di bagi dua, yaitu adat dengan pengertian "adat istiadat" yang merupakan suatu tradisi/kebiasaan masyarakat yang berlaku di suatu daerah. Sedangkan "adat" dengan pengertian "hukum adat" merupakan tatanan aturan yang di kembangkan sebagai alat kontrol bagi masyarakat yang berlaku bagi masyarakat hukum adat tertentu.

Sesungguhnya pada saat ini di Aceh berlaku 3 (tiga) jenis hukum yaitu, hukum positif Nasional, hukum syariat dan hukum adat, semuanya mempunyai ruang kerja masing-masing yang berbeda-beda pula. Jenis kasus yang dapat di tangani oleh ketiga badan peradilan ini telah diatur dalam Qanun Aceh. Khusus untuk kasus-kasus yang boleh diselesaikan oleh peradilan adat telah diatur dalam Qanun Aceh Nomor 9 Tahun 2008 Tentang Pembinaan Kehidupan Adat dan Adat istiadat.

Bila melihat lebih jauh maka peradilan adat yang ada di Gampong akan memproses perkara secara hukum adat dengan peradilan adat yang ada di Gampong,bila suatu kasus sudah 
dilaporkan pada perangkat gampong (ureung tuha gampong), baik pada geuchiek, tuha peut, teungku iтиem atau pada sekretaris gampong oleh pihak yang terlibat dalam perkara. Biasanya tanpa laporan dari masyarakat pihak perangkat gampong tidak menghiraukan perkara-perkara ada, karena menganggap para pihak dapat menyelesikannya sendiri, kecuali perkara yang sakral, seperti penganiayaan, dan mengganggu ketertiban umum, dll.

Bila suatu kasus tidak dapat lagi diselesaikan secara adat oleh pihak Gampong, maka akan memberikan wewenang untuk diselesaikan oleh Mukim dengan persetujuanpara pihak peradilan Mukim diselenggarakan. Kendati demikian, ada juga setelah peradilan di tinggkat Gampong sudah tidak mampu menyelesaikan perkara/sengketa, maka para pihak memilih sendiri apakah perkara/sengketa diselesaikan di tingkat Mukim atau di naikkan ke pengadilan Nasional.

Sesungguhnya didalam kehidupan bermasyarakat, Aceh memiliki berbagai aneka ragam adat yang diterapkan dalam kehidupan keseharian secara turun temurun, jenis adat yang di warisi salah satunya adat yang berkaitan dengan penyelesaian sengketa pada masyarakat. Didalam Qanun Provinsi Aceh No.10 Tahun 2008 tentang Lembaga Adat telah menetapkan 13 (tiga belas) lembaga adat, Adapun tugas dan wewenang lembaga peradilan adat Aceh tersebut adalah sebagai berikut :

a) Majelis Adat Aceh;

Merupakan suatu organisasi kemasyarakatan, yang dibentuk oleh suatu masyarakat hukum adat guna untuk peningkatan, pembinaan dan pelestarian adat istiadat.

b) Imeum Mukim atau nama lain;

Merupakan institusi pemerintahan adat dibawah kecamatan yang tergabung dari beberapa gampong dalam struktur kemukiman setempat, untuk menyelenggarakan pemerintahan Mukim dalam rangka mewujudkan kesejahteraan dan kehidupan berdemokrasi dalam wilayah kemukiman, melestarikan adat istiadat setempat melindungi fungsi ekologi dan sumberdaya alam dan juga menyelenggarakan peradilan adat di tingkat Mukim.

c) Imeum Chik atau nama lain;

Merupakan unsur pelaksanaan keagamaan dan peningkatan peribadatan serta pelaksanaan Syari'at Islam dalam kehidupan masyarakat serta mengurus, menyelenggarakan dan memimpin seluruh kegiatan yang berkenaan dengan pemeliharaan dan pemakmuran masjid, menjaga dan memelihara nilai-nilai adat, agar tidak bertentangan dengan Syari'at Islam, juga anggota dalam setiap musyawarah untuk menyelesaikan sengketa-sengketa dalam masyarakat ditingkat Mukim

d) Keuchik atau Kepala Desa;

Merupakan perangkat pemerintahan di gampong/desa yang bertugas membina kehidupan beragama dan pelaksanaan Syari'at Islam dalam masyarakat, menjaga dan memelihara adat dan adat istiadat yang hidup dan berkembang dalam masyarakat, memimpin penyelenggaraan pemerintahan gampong, sebagai pimpinan dalam menyelesaikan masalah sosial kemasyarakatan dan menjadi pendamai terhadap perselisihan antar penduduk dalam gampong.

e) Tuha Peut atau nama lain;

Merupakan institusi gampong/desa yang terdiri dari 4 (empat) orang, yang merupakan pilihan masyarakat yang di pandang cakap, berakhlak mulia, berpengalaman dan berwibawa untuk mendampingi geuchik sebagai penasehat, termasuk menjadi anggota dalam setiap musyawarah untuk menyelesaikan sengketa-sengketa dalam masyarakat, Tuha Peut ini bisa dianggap sebagai dewan di gampong. Empat unsur Tuha Peut ini terdiri dari Ulama, tokoh adat, pemerintahan, dan tokoh masyarakat yang tinggal dan menetap di gampong tersebut.

f) Tuha Lapan atau nama lain;

Merupakan penjabaran dari perangkat institusi Tuha Peut gampong guna kelengkapan unsur dan terpenuhinya kebutuhan sosial masyarakat didalam gampong sehingga di bentuknya 
Tuha Lapan, penambahan ini terdiri dari intelektual, pemuda, wanita, dan hartawan. Penggunaan atau keterlibatan Tuha Lapan ini biasanya pada hal-hal yang lebih sacral atau pada masalah-masalah yang lebih rumit atau besar.

g) Imeum meunasah atau nama lain;

Disebut juga dengan Teungku, Merupakan A'lim/ atau mempunyai pengetahuan agama Islam yang lebih kental sebagai pimpinan keagamaan didalam gampong yang dipilih oleh masyarakat secara terbuka/ langsung. Teungku Imuem Meunasah ini mengembani tugas memimpin masyarakat dibidang agama Islam, dan dalam musyawarah penyelesaiaan sengketa menjadi anggota musyawarah di tingkat Gampong demi terjaganya khasanah yang sesuai dengan syari'at dan mengeluarkan dalil-dalil keislaman sebagai alasan hukum.

h) Keujruen blang atau nama lain;

Merupakan satuan kelompok masyarakat hukum adat yang membidangi masalah persawahan, Keujruen Blang atau nama lain terdiri dari Keujruen Muda atau nama lain dan Keujruen Chik atau nama lain, yang bertugas secara otonom dalam menentukan dan mengkoordinasikan tata cara turun ke sawah, mengatur pembagian air ke sawah petani, membantu pemerintah dalam bidang pertanian, mengkoordinasikan khanduri atau upacara lainnya yang berkaitan dengan adat dalam usaha pertanian sawah, memberi teguran atau sanksi kepada petani yang melanggar aturan-aturan adat meugoe (bersawah) atau tidak melaksanakan kewajiban lain dalam sistem pelaksanaan pertanian sawah secara adat dan menyelesaikan sengketa antar petani yang berkaitan dengan pelaksanaan usaha pertanian sawah.

i) Panglima laot atau nama lain;

Merupakan satuan organisasi masyarakat hukum adat yang membidangi masalah kelautan, bertugas secara otonom dalam menangani sengketa-sengketa di laut, selain itu juga menentukan tata tertib penangkapan ikan atau meupayang termasuk menentukan bagi hasil dan hari-hari pantang melaut, menyelesaikan sengketa adat dan perselisihan yang terjadi di kalangan nelayan. Penyelesaiaan sengketa ini juga berkaiatan dengan yang terjadi antar Panglima Laot lhok atau nama lain dan mengkoordinasikan pelaksanaan hukum adat laot, peningkatan sumber daya dan advokasi kebijakan bidang kelautan dan perikanan untuk peningkatan kesejahteraan nelayan.

Berikut merupakan fungsi dan tugas Panglima Laot :

a. Panglima Laot lhok atau nama lain dan Panglima Laot kab/kota atau nama lain sebagai ketua adat bagi masyarakat nelayan;

b. Panglima Laot lhok atau nama lain dan Panglima Laot kab/kota atau nama lain, sebagai penghubung antara pemerintah dan masyarakat nelayan; dan

c. mitra Pemerintah dalam menyukseskan program pembangunan perikanan dan kelautan.

Panglima Laot ini terdiri dari 3 kelompok, yaitu:

1. Panglima Laot lhok atau nama lain mempunyai tugas:

a. melaksanakan dan memelihara serta mengawasi pelaksanaan adat istiadat dan hukum adat laot;

b. membantu Pemerintah dalam bidang perikanan dan kelautan;

c. menyelesaikan sengketa dan perselisihan yang terjadi diantara nelayan sesuai dengan ketentuan hukum adat laot;

d. menjaga dan melestarikan fungsi lingkungan kawasan pesisir dan laut;

e. memperjuangkan peningkatan taraf hidup masyarakat nelayan;

f. mencegah terjadinya penangkapan ikan secara ilegal.

2. Panglima Laot kab/kota atau nama lain mempunyai tugas:

a. melaksanakan tugas-tugas yang bersifat lintas laot lhok atau nama lain;

b. menyelesaikan sengketa antar Panglima Laot lhok atau nama lain. 
3. Panglima Laot Aceh atau nama lain mempunyai tugas:

a. melaksanakan tugas-tugas sebagaimana yang bersifat lintas kab/kota;

b. memberikan advokasi kebijakan kelautan dan perikanan serta memberikan bantuan hukum kepada nelayan yang terdampar di negara lain dan

c. mengkoordinasikan pelaksanaan hukum adat laot.

j) Pawang Glee/Uteun atau nama lain;

Merupakan pemimpin yang mengatur adat-istiadat yang berkenaan dengan pengelolaan dan pelestarian lingkungan hutan, bertugas secara otonom serta mengkoordinir pelaksanaan upacara adat yang berkaitan dengan hutan dan juga menyelesaikan sengketa antara warga masyarakat dalam pemanfaatan hutan.

k) Petua Seuneubok atau nama lain;

Merupakan sebuah organisasi adat yang fokus mengatur dan membagi tanah lahan garapan dalam kawasan Seuneubok, yang bertugas secara otonom, menyelesaikan sengketa yang terjadi dalam wilayah Seuneubok, mengurus dan mengawasi pelaksanaan upacara adat dalam wilayah Seuneubok serta melaksanakan dan menjaga hukum adat dalam wilayah Seuneubok.

1) Haria Peukan atau nama lain;

Merupakan sebuah organisasi adat yang bertugas secara otonom, dibentuk untuk mengurus pasar-pasar tradisional seperti membantu pemerintah dalam mengatur tata pasar, ketertiban, keamanan, menegakkan adat dan hukum adat dalam pelaksanaan berbagai aktifitas peukan, menjaga kebersihan peukan atau nama lain, menyelesaikan sengketa yang terjadi di peukan.

m) Syahbanda atau nama lain;

Merupakan satuan masyarakat hukum adat yang bertugas secara otonom dalam mengurus masalah pelabuahan rakyat, mengelola pemanfaatan pelabuhan rakyat, menjaga ketertiban, keamanan di wilayah pelabuhan rakyat, menyelesaikan sengketa yang terjadi di wilayah pelabuhan rakyat, serta mengatur hak dan kewajiban yang berkaitan dengan pemanfaatan pelabuhan.

Badan penyelesaian perkara peradilan adat di Aceh yang tergabung dalam majelis adat pada umumnya menyelenggarakan peradilan perdamaian adat di tingkat peradilan adat Gampong dan peradilan Mukim.

Menurut Qanun Aceh Nomor 9 Tahun 2008 Tentang Pembinaan Adat dan Adat Istiadat didalam pasal 13 telah disebutkan sengketa/ perselisihan adat dan adat istiadat meliputi berbagai persoalan yang terjadi di dalam masyarakat. Qanun ini tidak membatasi kewenangan diluar peradialan adat, berarti tidak tertutup kemungkinan bagi peradilan adat untuk menyelesaikan semua masalah yang terjadi di dalam masyarakat. Namun hal ini telah ada kerjasama dengan Polda Aceh untuk membagi kewenangan, seperti tindak pidana ringan (tipiring) dapat di selesaikan di peradilan adat di gampong. Ruang lingkup penanganan sengketa yang dapat diselesaikan oleh peradilan adat dapat dilihat pada tabel berikut yang meliputi :

Tabel 1. Kewenangan Peradilan Adat

\begin{tabular}{|c|c|}
\hline $\begin{array}{c}\text { KEWENANGAN } \\
\text { PERADILAN ADAT }\end{array}$ & $\begin{array}{c}\text { BEBERAPA KASUS DI LUAR } \\
\text { KEWENANGAN PERADILAN ADAT }\end{array}$ \\
\hline $\begin{array}{ll}\text { - } & \text { Perselisihan Dalam Rumah Tangga } \\
\text { - } & \text { Sengketa Antara Keluarga Yang Berkaitan } \\
& \text { Dengan Faraidh } \\
\text { - } & \text { Perselisihan Antar Warga } \\
\text { - } & \text { Khalwat/Meusum } \\
\text { - } & \text { Perselisihan Tentang Hak Milik } \\
\text { - Pencurian Dalam Keluarga (Pencurian }\end{array}$ & $\begin{array}{ll}\text { - } & \text { Pembunuhan } \\
\text { - } & \text { Perzinahan } \\
\text { - } & \text { Pemerkosaan } \\
\text { - } & \text { Narkoba } \\
\text { - } & \text { Pencurian Berat Seperti (Pencurian } \\
& \text { Sepeda Motor Dan Lain-Lain) } \\
\text { - Suversif }\end{array}$ \\
\hline
\end{tabular}




\begin{tabular}{|c|c|}
\hline 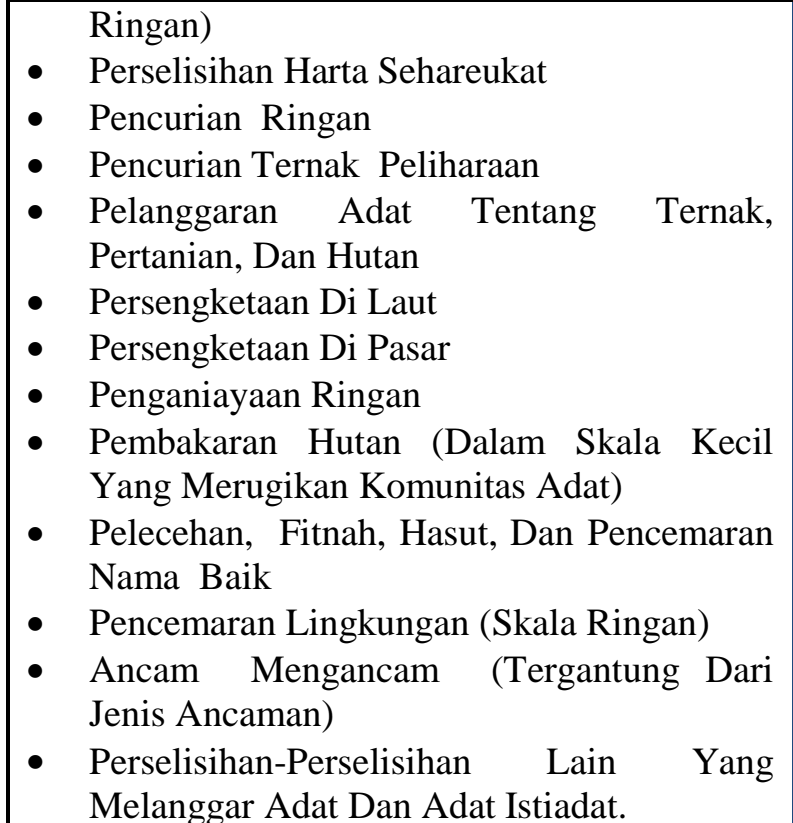 & $\begin{array}{ll}\text { - } & \text { Penghinaan Terhadap Pemerintah } \\
& \text { (Gubernur Dan/Atau Presiden) } \\
\text { - } & \text { Kecelakaan Lalu Lintas Berat } \\
& \text { (Kematian) } \\
\text { - } & \text { Penculikan } \\
\text { - } & \text { Perampokan, Dll. }\end{array}$ \\
\hline
\end{tabular}

Sumber: Diolah peneliti dari berbagi sumber.

Namun sesuai dengan keputusan bersama antara Gubernur Aceh, Kepala Kepolisian Daerah Aceh dan ketua Majelis Adat Aceh dalam dictum Kesatu disebutkan bahwa sengketa atau atau perkara-perkara ringan wajib diselesaikan terlebih dahulu melalui peradilan adat. Dengan demikian, sebuah tingkat kepantasan atau kemudahan diperlukan pada waktu menentukan perkara mana yang sesuai untuk di selesaikan melalui peradilan adat ataukah peradilan formal.

\section{Dasar Hukum Majelis Adat Aceh Besar Dalam Mengembil Keputusan Sengketa Warisan.}

Didalam sistem hukum adat segala perbuatan yang bertentangan dengan peraturan hukum adat merupakan perbuatan-perbuatan illegal dan hukum adat mengenal pola ikhtiarikhtiar untuk memperbaiki, jika hukum itu di perkosa. Dengan demikian, setiap perbuatan yang menimbulkan gangguan yang menyebabkan kehidupan tidak seimbang dan menyebabkan reaksi dalam masyarakat maka perbuatan itu di pandang sebagai perbuatan melanggar hukum adat yang harus diselesaikan secara adil dan bijaksana melalui lembaga adat.

Betapa rasa keadilan menjadi dambaan masyarakat, bahkan semua umat manusia. Didalam membangun kehidupan bermasyarakat memang sering terjadi benturan antara individu dengan kelompok, kelompok dengan kelompok dan sebaliknya yang menyebabkan timbulnya sengketa/delik-delik hukum, bahkan tidak jarang menimbulkan konflik-konflik yang besar yang menyebabkan perlunya lembaga peradilan adat.

Baik dalam perkara warisan, peran Majelis Adat di tingkat Gampong atau Mukim adalah sebagai mediator dalam menyelesaikan sengketa warisan. Dalam setiap proses penyelesaian sengketa atau perselisihan menurut hukum adat di peradilan tingkat Gampong, maka yang berperan di dalamnya adalah geuchiek dan teungku imuem gampong, musyarawah dilakukan di tempat atau rumah orang yang meninggal atau almarhum/pewaris biasanya disebut rumoh tuha. Geuchik dan Teungku mempunyai tugas ganda yaitu sebagai mediator sekaligus sebagai komunikator dan disisi lain sebagai pemimpin musyawarah adat dan juru runding. Geuchik juga bertindak sebagai hakim atau juri damai. Setiap putusan yang diambil dalam musyawarah adat selalu dapat ditaati dan dijalankan, dan pada umumnya tidak ada lagi perselisihan dikemudian hari. 
Pelaksanaan peradilan adat yang dewasa ini didukung oleh sejumlah peraturan perundang-undangan. Dengan kata lain payung hukum pemberdayaan lembaga-lembaga adat dan hukum adat sangat memadai. Didalam berbagai peraturan perundang-undangan tersebut dinyatakan secara tegas bahwa penguatan hukum adat dan peradilan adat harus dimulai dari gampong dan mukim. Pada dasarnya sama, majelis adat disetiap daerah di Aceh tetap memiliki dasar hukum daerah masing-masing yang disebut dengan Qanun kabupaten/kota, yang dibuat berdasarkan Qanun Provinsi Aceh tentang adat, tunduk kepada peraturan perundang-undangan.

Berikut ini merupakan hukum-hukum dan peraturan utama yang menyengkut dengan pelaksanaan peradilan adat di Aceh:

1. Undang-Undang Dasar 1945, Pada pasal 18b

Ayat (1) menegaskan bahwa:

Negara mengakui dan menghormati satuan-satuan kepemerintahan daerah yang bersifat khusus atau istimewa yang diatur dengan undang-undang.

Ayat (2) menegskan bahwa:

Negara mengakui dan menghormati satuan-satuan masyarakat hukum adat seta hak-hak tradisionalnya sepanjang masih hidup dan sesuai dengan perkembangan masyarakat dan prinsip Negara Kesatuan Republik Indonesia yang diatur dalam undang-undang.

2. Undang- Undang Tahun 1999 Tentang penyelenggaraan Keistimewaan Aceh.

Pada pasal 6 dan 7 menegaskan bahwa daerah diberikan kewenangan untuk mengidupkan adat yang sesuai dengan syari'at islam

3. Undang-undang nomor 11 tahun 2006 Tentang Pemerintah Aceh, Bab XIII.

Mengenai lembaga adat pada [pasal 98 ayat (2)] mengatakan bahwa penyelesaiaan masalah sosial masyarakat secara adat ditempuh melalui lembaga adat.

4. Peraturan Daerah (Perda) Nomor 7 Tahun 2000 Tentang Penyelenggaraan Kehidupan Adat menegaskan bahwa Lembaga adat berfungsi sebagai pengontrol keamanan, ketentraman, kerukunan dan ketertiban masyarakat, seperti di tuangkan dalam :

a. (Pasal 5) menyelesaikan berbagai masalah sosial kemasyarakatan.

b. (Pasal 6 dan 10) menjadi hakim perdamaian dan diberikan prioritas oleh aparat penegak hukum untuk menyelesaikan berbagai kasus.

Perda Nomor 7 Tahun 2000 ini telah diganti dengan Qanun Nomor 9 tahun 2008 Tentang Penyelenggaraan Kehidupan Adat dan adat Istiadat. Dalam Qanun pengganti ini tetap menegaskan penegakan hukum patut untuk memberikan kesempatan terlebih dahulu untuk diselesaikan secara adat.

5. Qanun Aceh Nomor 5 Tahun 2003 tentang pemerintah Gampong, yang memberikan wewenang kepada pemerintah Gampong untuk menyelesaikan sengketa adat, menjaga dan memelihara kelestarian adat dan adat istiadat, memelihara ketentraman dan ketertiban serta mencegah munculnya perbuatan maksiat dalam masyarakat, bersama Tuha Peut dan Imuem Meunasah sebagai anggota peradilan.

6. Qanun Aceh Nomor 4 Tahun 2003 Tentang Pemerintah Mukim, yang memberi wewenang kepada mukim untuk Memutuskan dan menetapkan hukum, memelihara dan mengembangkan adat, menyelaenggarakan perdamaiaan adat, menyelesaikan dan memberikan keputusan-keputusan adat terhadap perselisihan dan pelanggaran adat, memperikan kepastian hukum terhadap suatu hal dan pembuktian lainnya menurut adat, menyelesaikan perkara yang berhubungan dengan adat dan adat istiadat.

7. Qanun Aceh Nomor 10 Tahun 2008 Tentang Lembaga Adat, yang menegaskan bahwa lembaga adat berfungsi sebagai wahana partisipasi masyarakat dalam menyelenggarakan pemerintahan, pembangunan, pembinaan masyarakat dan menyelesaikan masalah-masalah sosial yang timbul dalam masyarakat.

8. Kesepakatan bersama antara Kepala Kepolisian Daerah Aceh, Gubernur Aceh, Ketua Dewan Perwakilan Rakyat Aceh, Ketua Majelis Permusyawaratan Ulama Aceh, Ketua 
Majelis Adat Aceh, Rektor UIN Ar-Raniry, Presidium Balai Asyura Ureung Inong Aceh, Ketua Persatuan Wartawan Indonesia Aceh Dan Ketua Komite Nasional Pemuda Indonesia Aceh, tentang penitipan peran Forum Kemitraan Polisi dalam Masyarakat (FKPM) kedalam Tuha Peut Gampong.

9. Mou antara Gubernur, Polda dan MAA yang berkaitan dengan peradilan adat, antara lain menegaskan :

a. Mengakui bahwa lembaga peradilan adat sebagai lembaga peradilan perdamaian.

b. Memberikan kesempatan kepada peradilan adat untuk menyelesaikan terlebih dahulu masalah-masalah sosial yang timbul dalam masyarakat di Gampongdan Mukim, bila tidak tercapainya perdamaian maka selanjutnya dilimpahkan ke Pengadilan.

c. Membagi wewenang penanganan sengketa dengan Polda.

d. Menghendaki tertibnya administrasi peradilan adat.

10. Qanun Kabupaten Aceh Besar Nomor 6 Tahun 2009 Tentang Pembentukan Susunan Organisasi dan Tata Kerja Majelis Adat Kabupaten Aceh Besar, yang menegaskan bahwa MAA merupakan mitra Pemerintah Kabupaten dan DPRK, yang mempunya tugas membantu Bupati dalam menentuaka kebijakan penyelenggaraan kehidupan adat, mengembangkan dan melestarikan penyelenggaraan kehidupan adat, melaksanakan dan membina nilai-nilai sosial budaya yang hidup dan berkembang dalam masyarakat, dan memelihara juga memberdayakan lembaga-lembaga-lembaga adat yang hidup dan berkembang dalam masyarakat.

11. Qanun Al-Asyi

Pemehaman yang terkandung tentang adat dalam Qanun Al-Asyi yang di sebut juga dengan Qanun Mekuta Alam Al-Asyi atau Undang-Undang Dasar Kerajaan Aceh Darussalam yang telah banyak diadopsi oleh kerajaan-kerajaan lain pada masanya yaitu :

a. bersumber dari Al-Qur'an, Al-Hadish, Ijma' Ulama dan Qiash yang telah menetapkan 4 (empat) sumber hukum bagi kerajaan Aceh, adalah sebagai beriku :

1. Kekuasaan Hukum (Yudikatif) di pegang oleh Qadhi Malikul Adil

2. Kekuasaan adat (eksekutif) di pegang oleh Sultan Malikul Adil

3. Kekuasaan Qanun (legeslatif) dipegang oleh Majelis Mahkamah Rakyat

4. Kekuasaan Reusam (Hukum darurat) yang di pegang oleh penguasa tunggal, yaitu sultan sebagai penguasa tertinggi sewaktu kerajaan dalam keadaan perang.

b. Qanun Mekuta Alam Al-Asyi dengan tegas mengemukakan bahwa sumber hukum Kerajaan Aceh Darussalam berasal dari Al-Qur'an, Hadish Nabi, Ijma' Ulama Ahlussunah Wal Jama'ah, dan Qiash, adapun jenis hukum Islam yang terkandung dalam Qanun Meukuta Alam Al-Asyi adalah :

1. Adat Syar'i, Hukum Syar'i, Qanun Syar'i, Reusam Syar'i.

Merupakan Dasar Hukum atau Undang-Undang Dasar yang mengatur Kerajaan, Keagamaan, Kemasyarakatan, demi terwujudnya ketentraman.

2. Adat Aridhi, Hukum aridhi, Qanun Aridhi.

Merupakan peraturan-peraturan yang di buat oleh pemerintah (Sultan atau wazir/Menteri) untuk mengatur masalah Kerajaan, keagamaan, kemasyarakatan dan ketentraman.

3. Adat Dharuri, Hukum Dharuri, Qanun Dharuri, Reusam Dharuri.

Merupakan peraturan darurat/Undang-Undang darurat yang langsung dibuat dan dijalankan oleh sultan sebagai penguasa tertinggi angkatan perang, untuk mengatur masalah kedaulatan Kerajaan bila dalam keadaan perang.

4. Adat Nafsi , Hukum Nafsi, Qanun Nafsi, Reusam Nafsi.

Merupakan peraturan istimewa yang dibuat khusus oleh Sultan untuk mengatur masalah agama dan sosial dalam masyarakat.

5. Adat Urfi, Hukum Urfi, Qanun Urfi, Reusam Urfi. 
Merupakan peraturan-perturan yang di buat oleh penguasa kerajaan-kerajaan kecil/penguasa daerah yang tergabung dalam Kerajaan Aceh Darussalam untuk mengatur wilayah dan masyarakatnya.

Sampai saat ini Qanun Meukuta Alam Al-Asyi masih berlaku di Aceh, walupun tidak seluruhnya/sepenuhnya dapat di terapkan dikarenakan pengaruh perkembangan masyarakat dan kedaulatan Negara Indonesia. Qanun ini merupakan pedoman dan asal muasal untuk menjalankan adat oleh Majelis Adat Aceh.

Kendati dimikian, adat peura'e (faraid) atau adat pembagian warisan di Aceh tetap juga berpegang teguh pada ajaran Islam, yaitu dengan kaedah Islah dan Shulhu, adalah :

a. Ishlah berasal dari bahasa Arab yaitu memperbaiki, mendamaikan, dan menghilangkan sengketa. Berusaha menciptakan perdamaian dan membawa keharmonisan, menganjurkan orang untuk berdamai antara satu dan lainya, melakukan perbuatan baik berprilaku sebagai orang baik adalah bentuk-bentuk dari Ishlah. Disebut dalam Al-Qur'an yaitu dalam Surah Al-Baqarah ayat 220 dan 228, di Surah An-Nisa' ayat 35 dan 113, Surah Hud ayat 87, serta surah Al-A'raf ayat 55 dan 85.

b. Shulhu berasal dari bahasa Arab (Al-Shulh) yaitu Akad yang memutuskan perselisihan kedua belah pihak yang bertengkar.suatu usaha yang mendamaikan kedua belah pihak yang berselisih, bertengkar, saling dendam, dan bermusuhan dalam mempertahankan hak, dengan usaha tersebut dapat diharapkan berakhirnya perselisihan. Disebut dalam AlQur'an yaitu dalam Surah Al- Hujarat ayat 9 dan 10, Surah Al-Baqarah ayat 182, Surah An-Nisa' ayat 114.

\section{SIMPULAN}

Berdasarkan penelitian dan pembahasan diatas, maka dapat ditarik kesimpulan adalah sebagai berikut :

Pertama, sesuai dengan Qanun Aceh Nomor 9 Tahun 2008 Tentang Pembinaan Adat dan Adat Istiadat didalam pasal 13 telah disebutkan sengketa/ perselisihan adat dan adat istiadat meliputi berbagai persoalan yang terjadi di dalam masyarakat. Dalam Qanun ini tidak membatasi kewenangan diluar peradialan adat, berarti tidak tertutup kemungkinan bagi peradilan adat untuk menyelesaikan semua masalah yang terjadi di dalam masyarakat. Namun hal ini telah ada kerjasama dengan Polda Aceh untuk membagi kewenangan, seperti tindak pidana ringan (tipiring) dapat di selesaikan di peradilan adat di gampong. Sedangkan yang menjadi dasar hukum Majelis Adat Aceh dalam mengambil keputusan sengketa warisan adalah Undang-Undang Tahun 1999 Tentang penyelenggaraan Keistimewaan Aceh, Undang-Undang Nomor 11 Tahun 2006 Tentang Pemerintah Aceh dan beberapa Qanun Aceh tentang Pemerintahan Gampong, Pemerintahan Mukim Serta Qanun tentang lembaga adat Aceh. Kedua, setiap perselisihan yang terjadi mengenai warisan, maka masyarakat lebih dominan untuk menyelesaikannya secara kekeluargaan, yaitu melalui perangkat adat,dan setiap putusan yang diambil oleh perangkat adat pada umumnya selalu ditaati dengan baik dan efektif sehingga tidak lagi menimbulkan perselisihan dikemudian hari.

\section{REFERENSI}

Buku

Abdurrahaman. 2009. Peradilan Adat di Aceh sebagai Sarana Kerukunan Masyarakat,Banda Aceh: Majelis Adat Aceh (MAA) Provinsi Aceh

Anonimos. 2003.Sistem Peradilan Adat dan Lokal di Indonesia; Peluang dan Tantangan, t.tp.: Aliansi Masyarakat Adat Nusantara (AMAN) dengan Dukungan dari Patnership for Governance Reform

B. Ter Harr Bzn, 1973. Hukum adat dalam polemik ilmiah, Bhratara

Mahadi. 1980. laporan hasil pengkajian bidang hukum adat, BPHN 
Soerjono Soekanto. 1988. Efektivitas Hukum dan Penerapan Sanksi Bandung: CV.Ramadja Karya

B.ismail, 2015 Peradilan Adat Sebagai Peradilan Alternatif Dalam SistemPeradilan Di Indonesia (Peradilan Adat Di Aceh)-2, Majelis Adat Aceh

I. Sulaiman dan T. Syamsuddin. 2002. Pedoman Adat Aceh:Peradilan Adat dan Hukum Adat, Lembaga Kebudayaan dan Adat Aceh (LAKA)

Tim Penyusun. 1997. Ensiklopedi Hukum Islam, Jakarta: PT. Intermansa

I. Taqiyuddin Abubakar Bin Muhammad Al-Husaini. 2003. Kifayah Al-Akhyar, PT Al Makrif, tt, Bandung

Wahbah Zuhaili. 2005. Al-Fiqih Al-Islami Wa Adillatuhu, Beirut: dar al-fikr al-muashir

Surojo Wignjodipuro. 1979. Pengantar Dan Azaz-Azaz Hukum Adat, Alumni, Bandung

Peraturan Perundang-Undangan

Undang-Undang Dasar Republik Indonesia Tahun 1945.

Qanun Aceh Nomor 5 Tahun 2003 Tentang Pemerintahan Gampong

Qanun Aceh Nomor 4 Tahun 2003 Tentang Mukim

Qanun Provinsi Aceh No.10 Tahun 2008 tentang Lembaga Adat

\section{Jurnal}

Sulastriono Dan Aristya S.D. F. 2008. Jurnal Penerapan Norma Dan Asas-Asas Hukum Adat Dalam Praktik Peradilan Perdata: 12 